\title{
Virtual Reality and Its Applications in Education: Survey
}

\author{
Dorota Kamińska ${ }^{1}$ (), Tomasz Sapiński ${ }^{1}$, Sławomir Wiak ${ }^{1}$, Toomas Tikk $^{2}$, Rain Eric Haamer ${ }^{2}$, \\ Egils Avots ${ }^{2}$, Ahmed Helmi ${ }^{2}$, Cagri Ozcinar ${ }^{3}$ and Gholamreza Anbarjafari ${ }^{2,4, *}$ (i) \\ 1 Institute of Mechatronics and Information Systems, Lodz University of Technology, Stefanowskiego 18/22 \\ Str., 90-924 Lodz, Poland; dorota.kaminska@p.lodz.pl (D.K.); tomasz.spanski@p.lodz.pl (T.S.); \\ slawomir.wiak@p.lodz.pl (S.W.) \\ 2 iCV Research Lab, Institute of Technology, University of Tartu, Tratu 50411, Estonia; \\ toomas@icv.tuit.ut.ee (T.T.); eric@icv.tuit.ut.ee (R.E.H.); ea@icv.tuit.ut.ee (E.A.); ahmed@icv.tuit.ut.ee (A.H.) \\ 3 School of Computer Science and Statistics, Trinity College Dublin, 2 Dublin, Ireland; ozcinarc@scss.tcd.ie \\ 4 Department of Electrical and Electronic Engineering, Hasan Kalyoncu University, Gaziantep, Turkey \\ * Correspondence: shb@icv.tuit.ut.ee
}

Received: 20 September 2019; Accepted: 12 October 2019; Published: 16 October 2019

\begin{abstract}
In the education process, students face problems with understanding due to the complexity, necessity of abstract thinking and concepts. More and more educational centres around the world have started to introduce powerful new technology-based tools that help meet the needs of the diverse student population. Over the last several years, virtual reality (VR) has moved from being the purview of gaming to professional development. It plays an important role in teaching process, providing an interesting and engaging way of acquiring information. What follows is an overview of the big trend, opportunities and concerns associated with VR in education. We present new opportunities in VR and put together the most interesting, recent virtual reality applications used in education in relation to several education areas such as general, engineering and health-related education. Additionally, this survey contributes by presenting methods for creating scenarios and different approaches for testing and validation. Lastly, we conclude and discuss future directions of VR and its potential to improve the learning experience.
\end{abstract}

Keywords: virtual reality; education; immersive education

\section{Introduction}

The term education generally refers to the process of facilitating learning, acquiring knowledge, skills or positive values. The main goal of education is to prepare students for life, work and citizenship by training their knowledge and skills deemed necessary in the society $[1,2]$. The educator's task is to improve qualifications, competencies and skills of graduates during the education path [3]. Usually, classes are divided into two parts: theoretical and practical, such as exercises, laboratories or internships. Theoretical courses consist of knowledge transfer in the form of lectures among a large group, which may contain discussions. Over time the needs of students and the the labour market forced changes in the education system [4,5]. Basing of the wisdom of Confucius who said, "Tell me and I forget, show me and I may remember, let me take part and I understand", the practical part had been made a priority.

Many students have problems understanding issues, especially the science courses, because of its technical complexity, a necessity of abstract thinking and the fact that those concepts are not entirely tangible [6,7]. Deficiencies in fundamentals prevent further development and exploration of more complicated problems. Practical exercises, mainly based on specialised research equipment, 
must be carried out under supervision; therefore, students cannot self-configure lab equipment, experience states of emergency or effects of misconfiguration which may lead to equipment damage. Moreover, there is no possibility to practice and catch up outside the laboratory schedule. Currently, the solutions are modern technologies such as online courses [8,9], blended learning [10-13], different computer-based platforms [14-18] and many others, which allow the students to repeat several times the same topic, make mistakes and learn from them. Numerous examples of hardware and software which have been successful in educational processes indicate that edtech industry can improve learning outcomes for the majority of students [19]. More and more educational centres around the world are starting to introduce powerful new technology tools that help them to meet the needs of diverse student populations. Traditional books are being replaced by digital instructional content (especially from open educational resources) [20]. Notebooks, tablets or cell phones with dedicated application have replaced classical copybooks [21]. Distance [22] and personalised learning [23] are used to tailor education to each student's academic strengths, weaknesses, preferences and goals.

It is well known that the use of information and communication technologies have been found to improve student attitudes towards learning [24-27]. It is a rapidly growing field of research, continually developing and looking for new technological solutions. Over the last several years, Virtual Reality (VR), which provides an interactive computer-generated environment, has moved from being the purview of the gaming to the professional development such as military, psychology, medicine and teaching applications.

In 1987, Jaron Lanier, together with Steve Bryson, formulated the first definition of VR, which they described as follows, "VR is the use of computer technology to create the effect of an interactive three-dimensional world in which the objects have a sense of spatial presence" [28]. Another definition of VR found in literature is $I^{3}$ : Interaction + Immersion + Imagination [29]. Currently the $I^{3}$ paradigm is mainly achieved through the generation of visual, audio and less often tactile, smell or taste effects. Human brain has the capability to process these sensations and allows an abundant flow of information between the mind and the environment, creating the experience of reality. This means the perception of reality can be changed if the sensory information sent to the human brain is altered to provide fictive information.

In technical terms, VR is an artificial three-dimensional environment created by a computer and presented to a person in an interactive way. It refers to the computer simulation displaying an environment through which one can walk and interact with objects and simulated computer-generated people (avatars). Virtual environment is usually three-dimensional, and it often attempts to replicate the real world in its appearance and physical phenomena. It simulates the user's physical presence in an artificially generated world that allows interacting with the environment [30].

Nowadays, VR is mainly created by generating visual effects through head-mounted display (HMD) systems. An HDM is a device worn on the head or as part of a helmet with a built-in display and lenses, allowing the user to experience the virtual world with the help of a wide viewing angle, head and hand movements tracking as well as objects interacting by controllers [31]. Development of the first version of Oculus Rift contributed to the popularisation of VR and the interest in VR devices is continuously growing. The business role of HDMs is also increasing with companies such as Facebook, HTC, Google, Microsoft, and Sony. These giant companies are investing in the development of this technology and finding new applications for the hardware they manufacture [32]. Currently, there are many kinds of HMD devices on the market, such as stationary and efficient (e.g., Oculus Rift and HTC Vive) or the remote VR headset with smartphone solutions with less processing power [31]. The most popular models of HMDs are juxtaposed in Table 1. 
Table 1. Comparison of the most popular models of head mounted display systems for virtual reality (VR) used for educational purposes.

\begin{tabular}{|c|c|c|}
\hline Technology & Advantages & Disadvantages \\
\hline HTC Vive Pro & $\begin{array}{l}\text { DS: } 1440 \times 1600 \text { per eye } \\
\text { : FOV } \approx 110 \\
\text { - Tracking virtual controllers } 10 \mathrm{~m} \times 10 \mathrm{~m}\end{array}$ & $\begin{array}{l}\text { - Weight: } 550 \mathrm{~g} \\
\text { - Price } \approx 1099 \$ \\
\text { - Stationary/long setup time }\end{array}$ \\
\hline Oculus Quest & $\begin{array}{l}\text { - DS: } 1440 \times 1600 \text { per eye } \\
\text { : FOV } \approx 90 \\
\text { External virtual controllers } \\
\text { - Portable }\end{array}$ & $\begin{array}{l}\text { - Weight: } 571 \mathrm{~g} \\
\text { Price } \approx 500 \text { \$ }\end{array}$ \\
\hline Samsung Gear VR & $\begin{array}{l}\text { DS: } 1480 \times 1440 \text { per eye (smartphone dependant) } \\
\text { - Weight: } 345 \mathrm{~g}+\text { smartphone } \\
\text { - Price: } 130 € \\
\text { Portable }\end{array}$ & $\begin{array}{l}\text { - FOV } \approx 101 \\
\text { Low battery life } \\
\text { - Nomputation capabilities (smartphone dependant) } \\
\text { No positional tracking }\end{array}$ \\
\hline Google Cardboard & $\begin{array}{l}\text { - Weight } \approx \text { smartphone } \\
\text { - Price: } 7 € \\
\text { Portable }\end{array}$ & $\begin{array}{l}\text { - DS: smartphone dependant } \\
\text { FOV } \approx 90 \\
\text { - Low battery life } \\
\text { - No positional tracking (smartphone dependant) }\end{array}$ \\
\hline
\end{tabular}

VR is a powerful tool in supporting and facilitating learning and teaching processes. Many surveys and reports show that most students remembered what they saw in VR and concluded that VR is a more memorable environment than laboratory-based demonstrations [33-35]. Ultimately, the laboratory-based method (a less efficient form of learning) results in deficiencies in fundamental knowledge and practice of graduates, which may lead to an inability to react to challenges that arise in future workplaces. An innovative method for teaching and learning based on VR is proposed to tackle the problems. One of the main challenges in providing quality learning experience is to access relevant resources, which is associated with additional expenses. In their daily practice, teachers frequently face unavailability of modern technologies that are currently in use on the market, such as expensive tools used in robotics, electronic components, chemical reagents, medical materials, etc. Thus, their replicates in the form of 3D models with identical physical properties transferred to VR technology may be applied mainly in developing communities and countries around the world. VR environment allows educators to conduct learning activities which are difficult to implement during regular laboratory lessons [36]. What follows is an overview of the big trend, opportunities and concerns associated with VR technology in education.

This paper summarises recent VR advancements in education. In Section 2, we briefly introduce key aspects of VR in terms of hardware and software. Then, we discuss the most popular approaches in creating educational scenarios in Section 3, and put together the most interesting educational VR applications in Section refsec:apps. Furthermore, in Sections 4 and 5, we provide a comprehensive review of methods for evaluation of the effectiveness of such applications. We conclude this paper with discussions and potential future research in Section 6.

\section{Types of Virtual Educational Environments}

In case of education purposes, virtual platforms usually simulate the classroom or the laboratory. However, sometimes, they provide a safe environment to test scenarios that would be too difficult or dangerous to perform in real life [37]. In this paper, we propose a VR applications taxonomy based on the learning outcomes and objectives according to three categories [38]: remembering and understanding, using acquired knowledge in typical situation and using acquired knowledge in a challenging situation. As one can quickly notice, this taxonomy is strictly connected with the level of immersion, and therefore also with the hardware requirements (see Figure 1). 

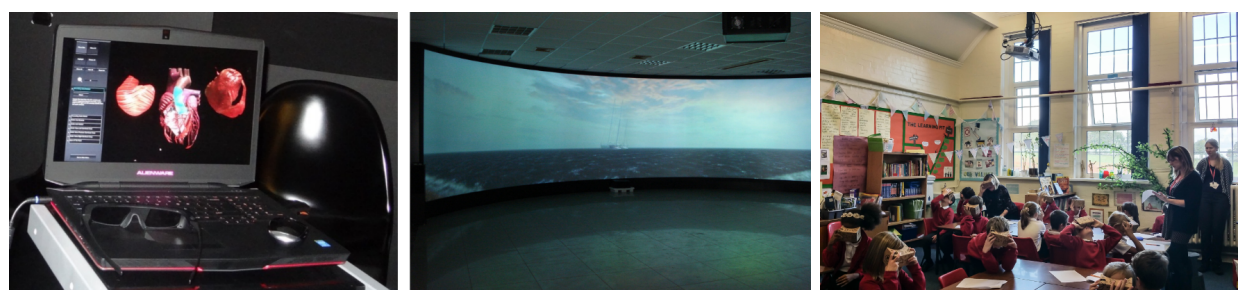

Figure 1. Different types of VR used for the purpose of education. From left: VR environment using common mouse/keyboard on a stereoscopic display [39], Experience room used to show tsunami [40], a Science educator in a primary school taking students to virtual Egypt via the Google Expeditions App [41].

The first type of VR platform is mainly used to present a state of knowledge in a particular field of science, supporting the students with acquiring theoretical knowledge, e.g., terminology, dates, facts, rules or scientific theories. Therefore, it usually requires the least immersive environment such as wall-based or monitor-based projection with special goggles or HMD with a simple input devices like keyboard, mouse, touchscreen or controller. Generally such scenarios consist of 3D visualisation [39,42], training in hazardous situation [43-45] as well as travel and space trips [46,47]. Very good examples are presented in [47], where the author summarises the impact of VR on history education. According to his thesis, VR lessons provide the opportunity to "move in time", students may witness historical events with their own eyes as well as experience historical places, architecture, clothes and people behaviour. The example of such application is Arnswalde VR [48], which recreates a Polish town destroyed in WWII. Using this app, students can walk through the streets of the city, enter buildings and experience a place that no longer exists. The same company created a virtual model of Auschwitz extermination camp. Google Expeditions, a platform for Google Cardboard, is a wireless fold-out cardboard viewer based on smart-phones. The Expeditions consists of a number of engaging projects, which can be used inside as well as outside the classroom, serving as an additional review of the material or homework [49-51]. Another example is a safety training [40], which consists of three main modules: firefighting, traffic accident and natural disaster, which are shown on ring-like screens with 3D capabilities. Children can experience different emergency situations, learn the appropriate actions and interact with the environment using controllers. The scenes in the modules use sounds from the real world and the correct distances between objects, and the scenes are made in a such way not to traumatise the children. In [39], semi-immersive environment is delivered through projection wall or 3D-Television with 3D glasses as well as on stereoscopic display (PC with a powerful graphic card and $3 \mathrm{D}$ glasses). The rotate manipulation of 3D data is based on motion capture-tracing gestures recognition or common mouse and keyboard, respectively.

The second type of VR platform is used to teach practical skills according to previously acquired knowledge. Such scenarios are divided into a presentation of theoretical knowledge (in the form of manual/presentation of requirements). This part will be, subsequently, imitated/copied by the student in the way of a practical task. This kind of application may require more profound immersive feeling and controlling. To address this issue, special external sensors, such as Kinect [18] or MYO Gesture Control Armband [52], sensor-gloves [53] or dedicated suits [54] might be needed. For example, in [55], the authors introduce an immersive system based on haptic interface simulating task-specific training in a hazardous work environment. To increase the realism of the simulation, they used HMD supported by a movement tracking device and feedback over multiple sensory (e.g., tactile) channels delivering modules. Lei et al. [56] present a VR application to improve children's abilities to learn science and social studies. In their application, they use Tilt Brush, which provides a 3D environment for painting.

The last type of VR platform is supposed to teach how to use acquired knowledge when faced with problems. In such scenarios, after gaining theoretical knowledge, students are put into virtual environment to deal with challenging tasks. Such tasks can be a formulating problem, analysing and synthesising new phenomena, formulating an action plan and valuing the situation according 
to specific criteria. This kind of scenario is mainly used in medical sciences and engineering, and it sometimes requires more advanced and high-precision educational systems supported by tailor-made haptic solutions. By practising with 3D models designed based on authentic devices, students may familiarise with their construction [57], principles [58], occurring physical phenomena [18] as well as experience states of emergency [59]. The Simodont [60], a VR application for teaching crown preparation in preclinical dental training, VR was combined with haptic feedback on the tools to simulate more realistic textures and feedback as compared to traditional false teeth. Such use cases are shown in Figure 2.

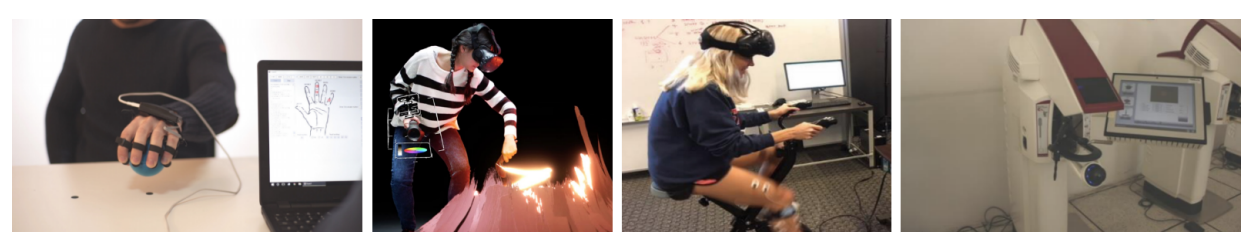

Figure 2. Selected examples that affect immersion level in VR-based education. From left: Immersive system based on wearable devices for providing on-the-job training [55]. Tilt Brushas: a tool in VR education [56]. Virtual Reality Cycling Platform [61]. Haptic feedback system used with Simodont for teaching dental procedures [60].

Apart from the above-mentioned taxonomy, all VR educational applications may be divided based on their autonomy (can be used independently by a student/requires the participation of a teacher/requires a group of students), the final user (for teacher/for student), the purpose (to learn/to practice/to check the knowledge/to present the knowledge) and the place of use (at home/in the classroom/in specific laboratory) [62-68].

VR can be used for self-study, but it can also be used by a tutor who may actively participate in the teaching process. In this case, the lesson is conducted by a real person, and VR serves as a tool which makes the lesson more interesting. A good example of such an approach is Google Expedition. In [69], the authors examined the potential role of VR support while conducting geography lessons. According to an analysis of the lesson-observations, the teacher reported that students generate more questions than during regular classes. Additionally, questions are more complex and have one or more of the following features; analytical, impact or evaluative. To automate the teaching process, a virtual teacher is very often introduced into a virtual environment. For example, in [70], the authors presented an intelligent tutoring system aiming to teach reading skills among students with autism. The environment consists of a virtual classroom, a pedagogical agent (tutor), and a humanoid robot with the role of a peer.

It is tempting to create multi-user applications to reflect the reality of teaching. Here, students are gathered in the same virtual environment where they can interact with each other. In [71], the authors evaluated several different multi-user virtual worlds based on collaborative learning in healthcare. The methodological quality of applications was assessed using the Medical Education Research Study Quality Instrument by 18 students. The average score is modest: 10/18. That is why the authors called for researchers to employ a more rigorous and broader approach to evaluation, which leads to the improvement of the quality of their work.

Unfortunately, there are very few research papers describing knowledge verification process in the virtual environment. In most cases, VR serves as a tool to learn and practice, but test and exams are still conducted in written form. VR exams are still the domain of distance learning [72]. Thus, there is a need for the creation of such application, which may report the student's progress or eventually lead to the final test/exam with automatic evaluation.

Several techniques are supporting the process of creating a VR educational scenario. For example, the authors in [56] proposed guidelines for educational VR applications based on the user study and expert interviews. Also, the application presented in [58] was developed based on design thinking methodology [73]. The application aim is to create a product tailored to the final user's needs based 
on empathy and deeper understanding. Regarding developing a medical application, scenarios are usually consulted with experts in a given field [74]

\section{Educational VR Applications}

In [75], the authors analysed a total of 99 papers implementing educational VR software. According to this survey, several application domains, such as health-related, engineering, science and general-purpose educational tools, were notably more prevalent. It was noticed that this trend has been occurring up to present; thus, in this section, we present the most interesting and recent applications related to those educational domains.

\subsection{Engineering Education}

Virtual environments are widely used as an engineering training simulators. The popularity of VR in this field can be attributed to the attractiveness of its use in preparing engineering students for real-world industrial situations, as well as allowing them to make early in-design decisions in a cost-effective manner [76]. It gives engineers a better understanding of the design and helps to facilitate the changes wherever necessary. Moreover, it helps to reduce the time and cost factor, which plague many modern design processes [77]. Figure 3 illustrates some of such applications.
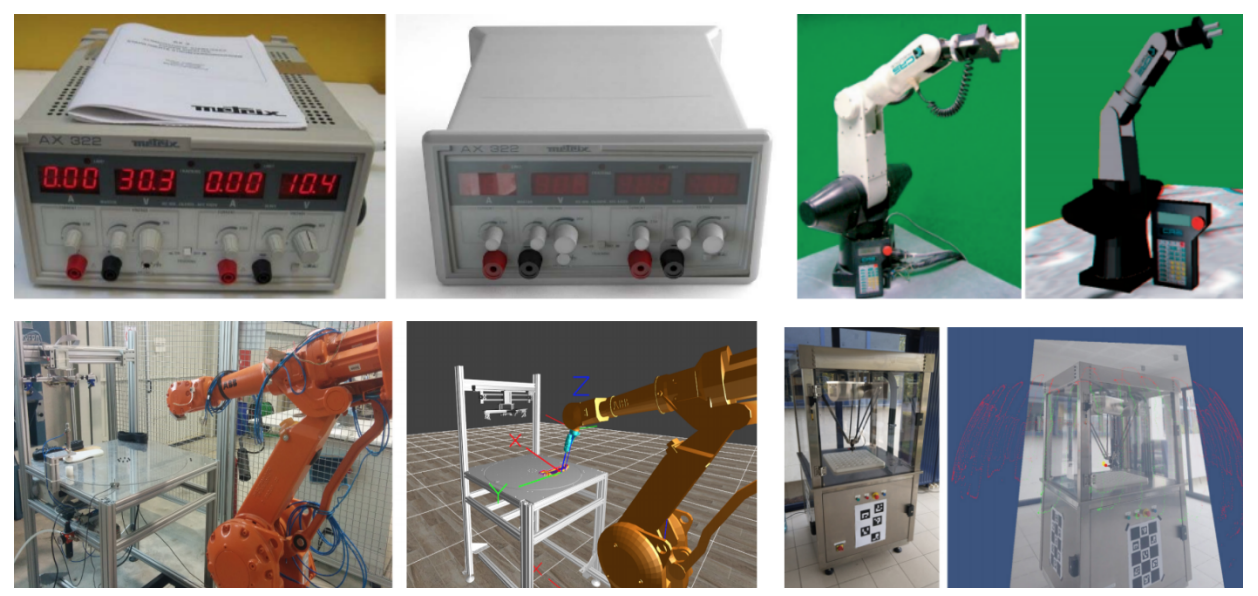

Figure 3. Real engineering labs and its representation in VR. From left: power block [78], CRS robotic arm [79], robotic cell for shoe-sole gluing [80] and industrial picking robot [81].

In this section, several state-of-the-art applications will be described briefly. Figure 3 presents screenshots of selected virtual environments for engineering education purpose. For instance, education of civil engineering was aimed in [82]. The goal of the project was to motivate and engage young students, as well as to allow them to understand planning issues often restricted by their current knowledge. The general aims in the project were to explain the role of civil engineering to K-12 students and their relevance to society. In their accompanying research [83], the authors created a VR platform to introduce civil engineering to pre-university students through a VR game. The obtained results show that VR is a relevant asset in Civil Engineering Education as it allows for participants with no prior training to properly interact with the platform. The authors of [78] presented a VR application to promote electrical engineering education. They designed and developed online laboratories that students could remotely access using VR. These projects enabled students to use virtual breadboards and virtual instruments to perform simple electronic laboratory work. The created application housed realistic 3D model prototypes of all of the equipment as well as relevant electrical components for the experiments. Virtual environments like these could be used in tandem with other study materials, allowing students to learn and participate from home or work. Also, it minimises the concerns of teachers regarding time, cost and risk of dangerous experimental strategies. Sampio et al. [84] focused on producing 3D models that could be interacted with and provide better structural understanding for 
civil engineering students. The models were of roofs; walls, including all of the structural elements; and a bridge. The interaction with the models allowed both for monitoring the progress of construction and valuable information about each element.

A more interesting approach was presented in [79], where the authors created a VR system for robotics education and training. The application was equipped with both visual and haptic feedback based interaction and contained a built-in physics engine. Robotic arms can be controlled by either a virtual pendant or programmed to follow specific instructions. Results of using this application indicated that users trained on this system were better equipped for completing tasks on real robots compared to their counterparts who were briefed with traditional training materials. Similar approaches, with similar results, have also been presented in $[80,85]$. To ease the process of creating virtual models of existing machinery, the authors presented a new method of acquiring a 3D model based on image scanning [81]. Also, the authors presented Virtual Mechatronics Laboratory (ViMeLa) in [36]. The goal of this project is to enrich study programs by implementing a VR-based tool for teaching and learning mechatronics in higher education institutions. ViMeLa delivered a VRspace, where students could experiment with simple machinery which allows them to make and later learn from mistakes without real-world consequences (i.e., expensive dameage). A similar example was presented in [86], where the authors described a system for learning the inner operations of an intelligent factory, according to the concept of Industry 4.0.

\subsection{Medical Education}

Medical VR is an area with great opportunities, which is confirmed by many clinical researchers and real medical practitioners $[87,88]$. It helps physicians, nurses and students to improve the quality of medical skills through real-life scenarios, which provide an opportunity to learn-by-doing. Although the field is brand new, there are already great examples of VR applications having a positive effect on medical education. In this section, the most interesting VR medical educational applications are briefly described. Figure 4 presents screenshots of selected VR environments.
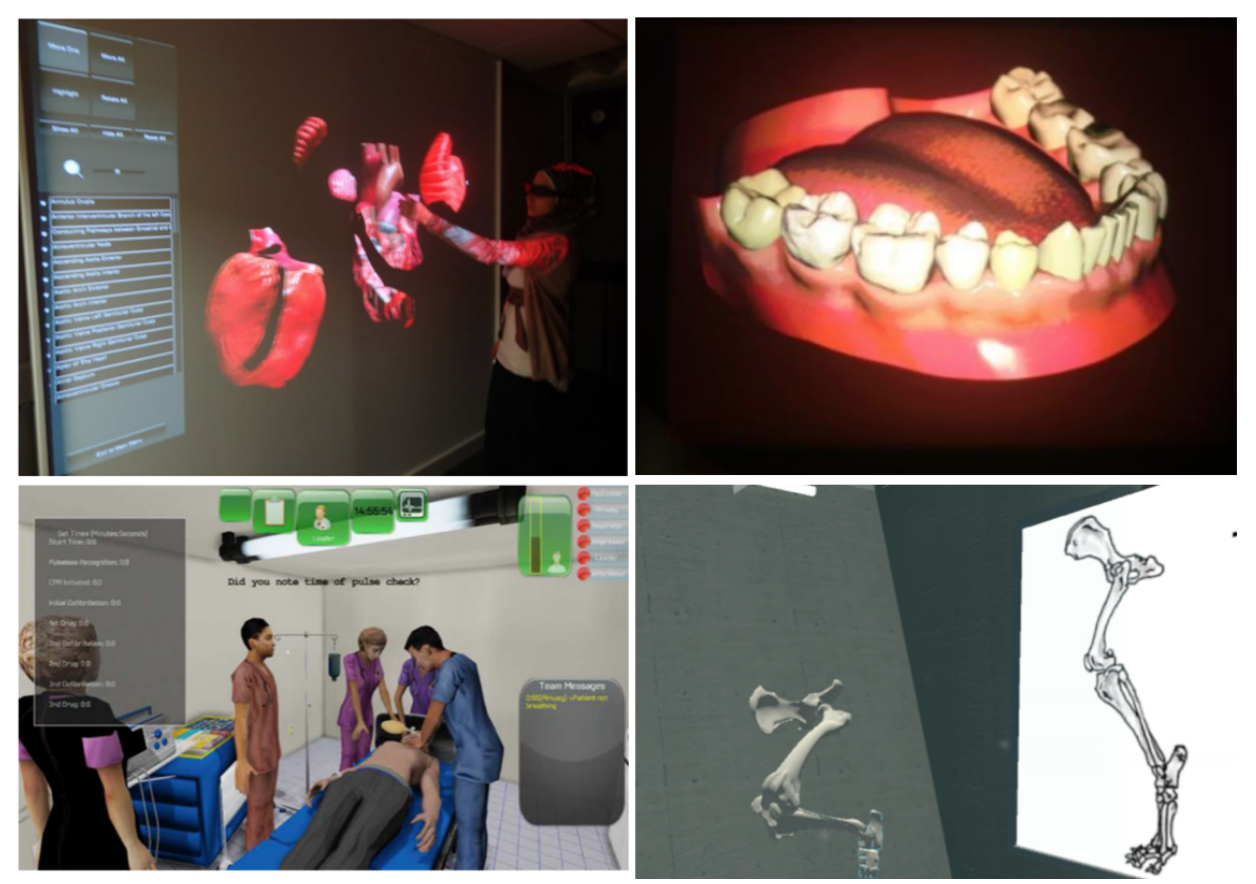

Figure 4. Screenshots of VR applications for medical education: A virtual reality heart anatomy system [39], Dental crown preparation training [60], Cardiac Life Support Training [89] and Anatomy Builder VR [90]. 
In [39], the authors present a VR system, which offers a real-time 3D representation of heart structure in an interactive environment. The application allows particular interaction, such as free manipulation, and models disassemble to present true anatomical relations of different parts of the heart. Different shades of flesh colours with slight exaggeration were used to achieve a realistic representation of the various structure of the model. Further, the position of the heart is set to the correct anatomical orientation. The application aims to help with understanding the complexity of heart structure. Also, it seeks to clarify the anatomical relations of its different parts. A similar approach is presented by Seo et al. in [90]. The main goal of the proposed application is to support learning in canine anatomy education. It allows the students to interact with either individual bones or groups of bones, to identify them and to assemble a real animal skeletal in 3D space.

Wang et al. [60] present Simodont-a 3D VR simulation system for dental crown preparation training. The simulator can distinguish dental students and prosthodontics residents both timeand skill-wise, thus establishing its validity as a teaching tool. As it offers realistic clinical situations, it allows students to practice more extensively than with phantom leads or plastic manikins. An exciting application is presented in [91]. The authors created a VR-based training simulation for advanced cardiac life support. The scenario consists of time-sensitive and team-based medical tasks provided guidance on the clinical interventions provided during cardiac arrest and respiratory failures. It is intended for newly formed clinicians teams, which need to practice the action of saving patients life. The authors of [92] present a VR simulation in nursing education. They recreated a real hospital ward, full of avatars of demented patients, their family members and hospital staff. This project aims to prepare students for the nursing role and to present their responsibilities in a realistic environment. The goal of the application showed in [93] is to improve the teaching of surgical hand preparation, which is a crucial practice in preventing post-surgical infection. In addition, VRmagic Eyesi Ophthalmic Surgical Simulator [89] provides realistic environment to acquire psychomotor skills and develop microsurgical spatial awareness, which may be applied to real-life cataract and vitreoretinal surgery. It is addressed to beginner ophthalmic surgeons to familiarise them with the safe handling of a patient's eye in a safe environment and to allay their stress in the operating theatre.

\subsection{Complex Educational Topics: Space Technology and Mathematics}

VR has introduced a new way of teaching astronomy and space technologies [94-96]. Mintz et al. proposed a new interactive virtual environment (VE), which employed a dynamic 3D model of the solar system [97]. The learner can enter a virtual model of the physical world. Then he/she can zoom in or out and change his/her viewpoint and perspective, while the created virtual world continues to operate in its natural manner. A significant advantage of such an education tool is creating the ability to travel in space and create a unique user experience for learners [98]. Other tools were also developed to display the astronomical objects in a way as astronauts see them in a spacecraft. The tools are aiming to preserve correct visible sizes of objects.

Existence of complexity in some courses makes them a perfect target for VR. For example, geometry in mathematics can be easily targeted for improvement by using VR [99-101]. Kaufmann et al. proposed an $\mathrm{eD}$ geometric construction tool based on the collaborative augmented reality system [102]. Pasqualotti and Freitas investigated the use of VEs in teaching and learning and proposed a conceptual model for the teaching and learning of mathematics [103].

\subsection{General Education}

VR may serve as a low-cost, easy-to-use user-friendly tool and resource [104-107]. There are a number of engaging projects that can be used in the classroom [108]. A great example is Google Expeditions, which allows the teacher to take an entire class on virtual trip. The application recreates an immersive experience of a real-world with 360-degree videos shot of different locations such as an underwater exploration of a coral reef in the South Pacific or the Louvre museum in Paris using Google Street View technology [109]. VEnvI (Virtual Environment Interactions) [110] is a visual programming 
tool that combines dance, computational thinking and embodied interaction. The system was created for high school girls to increase the appliance of STEM fields. The application of VEnvI and the immersive, first-person interaction were carried out as an activity of a summer camp for middle school girls. The participants of the program ( 54 girls between the ages of 11 through 14) had to use computer science and programming concepts to program dance moves for avatars. With the help of Oculus Rift HMD, the participants had the opportunity to be present with the virtual character they are programming, have a first-person perspective of the choreographed performance, make changes and correct mistakes. Some of such use cases are shown in Figure 5.
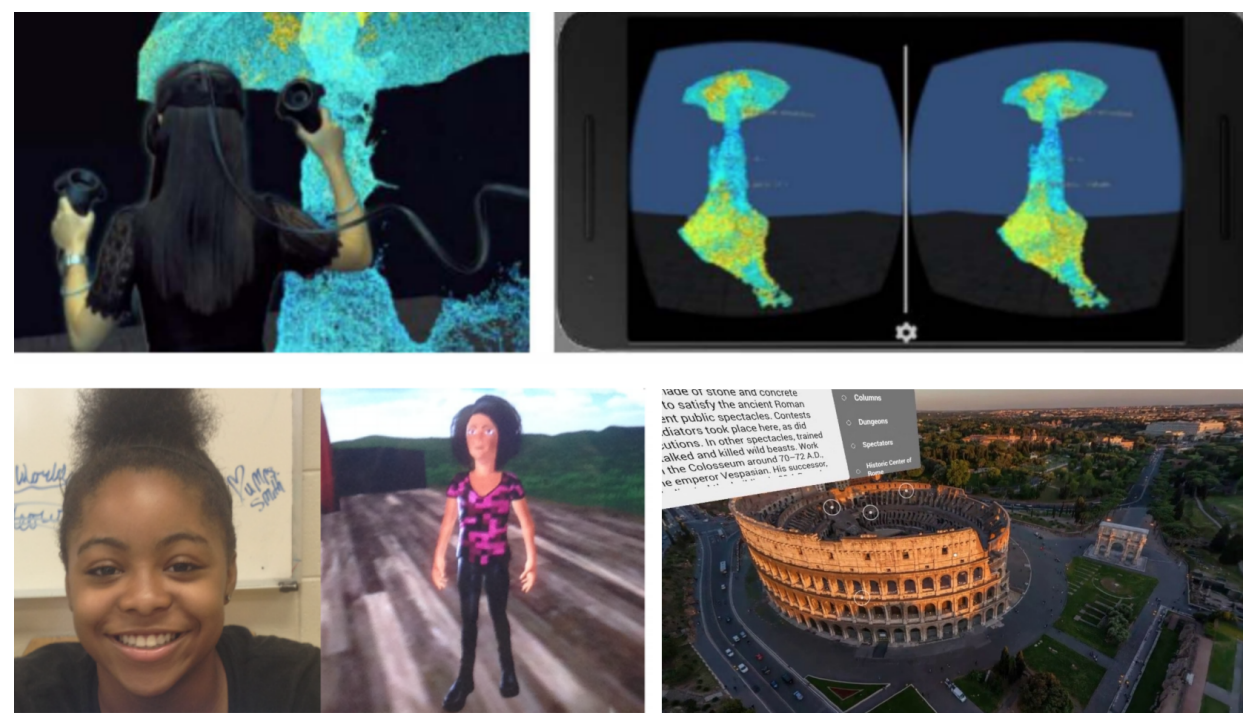

Figure 5. Screenshots of VR applications for general education: Top: Thrihnukar experience in the HTC Vive [42]. Bottom: left-Participant of VEnvI with her customised character [110]; right-Colosseum VR Tour by Google Expeditions [109].

One of the most important feature of VR interfaces is their potential for visualisation. Serafin et al. [111] proposed an alternative approach to acquiring musical skills. VR musical instruments VRMIs can stimulate intelligent visual feedback that may aid the player in performing. The performer can see the virtual flute through a 3D visualisation.

In [112], the authors discussed the features of VR technology and the roles of VR technology in PE. Applying VR technology in PE teaching and training might help engage students in their initiative by playing a significant role. The primary data collection devices are 3D locating and tracking devices, body movement capture devices, hand gesture input devices and other manual input devices. The VR training system software included a database system, a software application system and open-ended platforms.

Melatti et al. [113] presented a virtual toolbox designed for teachers to prepare and deliver instruction that could be viewed by students in the same virtual environment. A platform closely matches a classroom-sized space and gives the user complete transnational viewing angles. Students are positioned in the middle of VR classroom with a PowerPoint screen behind them. The advantages of such an application are that virtual tools can then be continually added to a software library. All teachers in the community can then reference this library repository and pull tools into their VR Classroom to create unique lectures.

The authors of [42] presented the use of VR for studying the geospatial and geologic data for Iceland's Thrihnukar volcano, provided a detailed description of this experience and discussed a long-term vision of creating an efficient and easy-to-follow platform, appropriate for researchers and teachers who are not VR programming experts. A photorealistic point cloud model, based on photos taken at the Thrihnukar volcano, creates an immersive experience and gives the user the ability to view and interact with the scene. 
Some other papers refer to teach safety practices in industrial manufacturing workplace $[114,115]$ or in dangerous conditions such as accidents [116] or disasters [40]. For example, Chittaro et al. [117] present a mobile VR serious game aimed at teaching how to don a life preserver on the aircraft. The environment reproduces a full 3D aircraft cabin environment, in which one can see their character in third-person view. The goal of the player is to make the character don the life preserver properly. The results of the study confirmed the effectiveness of such an approach. Here, participants, who used the VR tool, were able to transfer the safety knowledge to the real world significantly faster and with fewer errors than participants who used traditional safety briefing card. In [118], the authors prepare a system for critical incident decision support basing on virtual scenarios of chemical, biological, radiological, nuclear or explosive accidents and attacks. Another good example of such an application is presented in [119]. The authors create a VR simulation designed to train operating room professionals in OR fire prevention and control. Agrawal et al. present a VR headset-based latent hazard anticipation and mitigation training program of six high-risk driving scenarios for young drivers [120].

\subsection{Special Needs Education}

The literature is increasingly recognising the potential benefits of VR as a tool supporting the unique needs learning process. Many research indicates the critical role of this technology in improving the behavioural, communication and social skills of children who have autism spectrum disorder (ASD) [121]. In recent times, VR is being considered as the best method to monitor ASD intervention through VR- based human-computer everyday tasks, as can be seen in Figure 6.
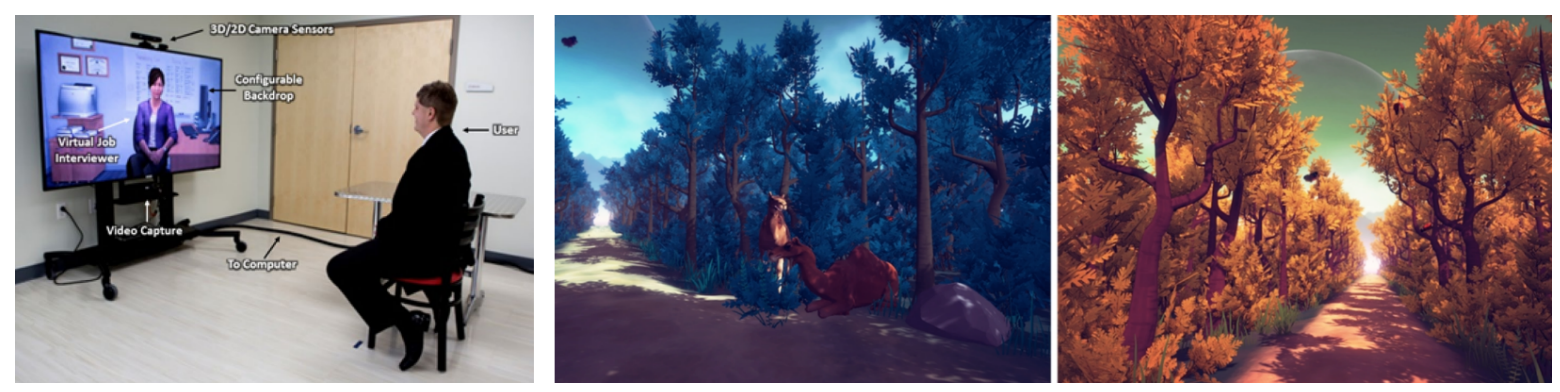

Figure 6. Screenshots of VR applications for special needs education: Left: User interacting with components of VR system [122]. Middle and Right: VR environment that participants moved through while walking on the treadmill [123].

For example, in [74], researchers present a VR enabled an application for enhancing emotional and social adaptation skills for children with ASD. The application consists of six unique learning scenarios: emotion control and relaxation, simulation of various social situations, facilitation of consolidation and generalisation. The app is designed and developed with corresponding psychoeducation procedures and protocols. In [124], VR is used to improve job-interviewing skills of high school students with ASD. Similarly, Burke et al. present a study, [122], of whether a virtual interactive training agent may improve job interviewing skills of people with autism and developmental disabilities. Their results are promising-all participants developed the ability to identify strengths, self-promote, self-advocate, answer situational questions and respond to behavioural/social questions.

VR can provide patients with a fun interactive environment as they can be guided to maintain high quality and intensive physiotherapy. Some current systems used in physiotherapies like BioTrak and IREX have high efficiency, although their prices are high. Thus, this leads to the necessities of low-cost options. The hardware, provided by the video game consoles emerged as a brilliant opportunity because it is designed to obtain the 3D position of game players in real-time. In [125], the authors present a VR tool for hand rehabilitation. The application in the form of a game has different options, tasks and exercises related to 3D grabbing, reaching, pointing, lifting, throwing and other activities for hand rehabilitation where the leap motion is the central concept of VR and physiotherapy. The authors of [126] describe the technologies and original designs available at LIRKIS Laboratory and their relation 
to the disabled people education. In [123], the authors investigate whether manipulations of spatial distance in VR can influence treadmill exercise performance in patients with intermittent claudication; a cramping pain or discomfort in the legs, which occurs during exercise. Ravi et al. [127] evaluate the effectiveness of VR systems used in the motor rehabilitation of children with cerebral palsy. In [128], the authors check the therapeutic effect of VR physiotherapy on gait balance and the occurrence of falls after a stroke. A group of 30 patients took part in clinical trial rehabilitation with Nintendo Wii. They use different games such as tennis, hula hoop, soccer and boxing, requiring the maintenance of balance. The clinical trial proves that interactive games are a useful tool for gait balance rehabilitation in post-stroke patients, with repercussions on the reduction of falls.

\section{Evaluation Methods}

New implemented application should be tested among relevant stakeholders and specified number of potential users. The product should be evaluated, taking its functionality, effectiveness and capabilities into account. In 1996, John Brook presented System Usability Scale (SUS) [129], which provides a reliable tool for measuring the usability. SUS consists of 10 item questionnaire with 5-point scales numbered from 1-strongly agree, to 5-strongly disagree. Based on the research, a SUS score above 68 is considered above the average and anything below 68 is below the average. Since then, it has been a widely used tool, as evidenced by the number of citations of the article. Unfortunately, although the tool is available, well-described and easy to use, there are precious few VR applications that are not evaluated or not evaluated enough [114]. Based on this baseline, it would be necessary to develop SUS for VR and adapt it to the educational applications.

Very often, testing procedure ends with several evaluating questions, less general or tailored for the purpose of specific application [130]. For example, in [58], the authors presented an interactive training strategy for mechanical and electrical engineering education. The application was tested by a group of 60 students (20 male and 40 female) who did not have any previous experience with VR. During a single session, the student was supposed to go through each of the available exercises and complete the interview. A similar test was conducted among 15 academics.

A more extensive procedure is presented in [110]. To investigate the long-term effects of their software, the authors conducted a study among sixth and seventh-grade students who took part in seven one-hour sessions over two weeks. The questionnaire, which included ratings and open questions, was divided into two parts: the first part focused on students' experience, and the second part was straightly connected with the the main goal of the study: a character customisation. Both parts were conducted twice, once at the beginning and once at the end of the experiment. The results showed how the presence or absence of character customisation might influence a learning system.

Another comprehensive evaluation is presented in [131], where the authors examined the influence of VR field trips on middle school students' social studies academic achievement and motivation. The experiment was conducted among 76 seventh grade students from two different middle schools who participated in social studies instruction, using either the traditional lecture method or a VR system. All participants were assessed using the Instructional Materials Motivation Survey, and their teacher designed social studies test. The results demonstrated that students using VR obtained scored significantly higher than students educated in a traditional method on both their academic achievement and motivation.

A group of disabled children was arranged to test VR system in the lab, and during the development of user interface including touch interface, the method has been applied of repeating processes of designing, testing and result evaluation. The development is in the stage of prototyping. The field-testing started in 2012 and also includes other solutions, such as software adjusted for deaf and mute children (sign language) [132]. The best results were achieved with the KPI-CGRS software. It was comfortable for children and well received by educators. During their first encounters with the tool, the children showed their natural playfulness, but after some time, they became used to the tool and were working with it without significant problems. In the KPI-CGRS the benefits also 
lie in the practical utilisation of available virtual reality equipment for gesture recognition processes. The advantage of the implemented sequence comparison method is in its capability to compare all forms of real-life sequences that can be represented in the form of vectors.

It is important to elaborately evaluate medical-nature applications, as they can affect human mental and physical health. Testing of ViTA [122] was evaluated by 32 participants between 19 and 31 years old. Almost $70 \%$ of the participants were diagnosed with ASD, $65 \%$ had an intellectual disability, and $25 \%$ reported the presence of other disabilities; it was confirmed through their vocational rehabilitation record and/or a psychological report. The effectiveness of this application was measured by the adjusted mean score difference between the first and the last session, and between consecutive sessions. This objective measurable demonstrated the significant improvement in the interviewing skills of participants.

From pedagogy perspective, there has been some researchers who has evaluated the application of VR in education [133-137]. Fowler presented a more pedagogical description using the concept of pedagogical immersion for mapping stages of learning onto types of learning environment [136]. In thr case of VR in education, pedagogy must be subordinate to story, which is being used for the the application.

\section{Challenges and Issues}

It was proved repeatedly that VR has great potential for positive educational outcomes by providing more engaging environment stimulating various perception points. Although, as long as it is a new delivery method for knowledge, it lacks the more in-depth research [138]. In this section, we present VR advancements in education and summarise the most important issues and drawbacks of using VR technology as an educational tool. The majority of modern existing VR solutions are based on HMDs, which provide a total immersion through 3D virtual environment imitating the reality. According to [37], one of the key issues that should be addressed in the very near feature is the lack of visual realism and realism of the dynamics and interaction. It can be concluded that existing techniques used to generate VR graphics and displaying technology are quite limited. Note that, psycho-visually, the human brain's construction allows us to detect even small unrealistic details, which can easily break the immersion. Thus, in the creation of the VR world, maximising the appearance of reality is an ongoing challenge.

Realistic VR environments require computationally powerful hardware for rendering, which goes hand in hand with the price. According to [37], high costs of developing or purchasing a VR system is a significant hurdle to overcome. Currently, tools providing high-end VR experiences, such as Oculus Rift or HTC Vive cost approximately $\$ 400-600$, respectively; they should be supported by computationally powerful PC, which is still a relatively expensive alternative to conventional methods of teaching. However, using HMDs bright immersive VR experiences into the homes and classes with much lower cost and space requirements than previous generations of VR hardware [139]. VR technology is under constant development, seeking low-cost, wearable solutions for the mass market. Professional technology companies provide products that incorporate mobile phones. For example, Samsung Gear VR, Google Daydream, or a more low-end Google Cardboard, are more accessible than the above mentioned high-end solutions (e.g., HTC Vive or Oculus), they do not require an additional computer, only a low-cost headset with a phone. However, experiences or simulations generated on mobile may not match the ones generated on a PC concerning immersion. Additionally, the mobile solutions have minimal interaction capabilities in comparison with what is achievable with high-end solutions. Nonetheless, the trade-off between accessibility and price might be the key factor in using the mobile solutions by a wider audience. Educational simulations might not require the highest available quality but are rather based on the content of the experience and possibility to provide a large number of headsets for a class of students at a significantly lower cost compared to high-end HMDs.

Human factor and physical side effects are another issues [37]. Recent reports suggested that the use of HMDs may have unwanted physical/physiological side effects such as anxiety, stress, 
addiction isolation and mood changes [140]. Further, simulated motions can affect one perception of time and space, inducing dizziness and nausea, called VR sickness or cybersickness [141]. For instance, in [142], 150 subjects were tested in an immersed virtual environment for $20 \mathrm{~min} ; 61 \%$ of subjects reported symptoms during 20-min immersion and a 10 -min post-immersion; $5 \%$ percent of the subjects had to withdraw from the experiment because of severe symptoms. The authors suggested the use of adaptation and the anti-motion sickness drug to reduce this kind of side effects. HMD worn on the head, due to unnatural postural demands, may have a negative effect on dissociation of accommodation/convergence and cardiovascular change [140].

However, there are only a few scientific studies presenting clinical trials on the effect of using HMDs. Notably, most of the scientific experiments were carried out using very early HMD technologies. Due to the technical advancements in HMD technology, new investigations are required in this domain. Furthermore, every man is unique and may have different perception; therefore, scenarios preparing for education, especially for kids or handicapped should be accurately examined and evaluated, consulted with professional psychologists and educators.

\section{Conclusions}

The education system has been evolving for centuries. It has always adapted to the available technology and needs of the students. We are now on the threshold of another development and it is a duty of scholars, educators and teachers to embrace it and prepare for it. The generation that is starting education right now has been online for whole their lives. Digital world is as important and immersive as the real one. They are digital natives, born onto the world of mobile phones, omnipresent Internet and immediate access to most of desired information or data, is it music, video or content. Educating Generation $\mathrm{Z}$ is a challenge and it requires a completely different approach to maximise efficiency and engagement.

There are numerous proven advantages of using VR technology in education. First of all, VR provides outstanding visualisation, which cannot be obtained in traditional classroom. It reflects the world that young generations feels comfortable in. It is inclusive, allowing everybody, everywhere, regardless of status, financial situation and disability to participate in education process. It gives virtually unlimited access to information, books or articles. Modern technology used in classroom increases engagement, stimulates cooperation and involvement. It is used for highly efficient blended learning, encouraging self-study and individual pursuit of knowledge.

Although using modern technology in education environment is clearly beneficial, it is not without risks or dangers. One of the main issue is the lack of flexibility. During traditional classes students may ask questions, receive answers, take part in this discussion. Using a virtual reality headset with specific software, the students have to follow the rules and are not able to do anything else except what they are supposed to do. Some educators are naturally resistant to change and their involvement and active participation is crucial for successful introduction of technology into the classroom. Others might tend to over rely on technological developments, leading to lack of teacher-student interaction. A human teacher is also a natural filter and moderator of information acquired by students, absolutely necessary to assess validity and relevance of obtained data. What is more, focusing too much on digital education solutions might distort the balance between teaching hard and soft skills, to the big advantage of the former, while the latter remains very important in the modern workplace. Although we might be tempted to replace all old-fashioned solutions with modern digital ones, there must be an equilibrium between state-of-the-art solutions and human interaction, mentoring and teacher-student relationship.

Author Contributions: Conceptualization, D.K., T.T, and G.A.; methodology, D.K., T.S., S.W. T.T., R.E.H., E.A., A.H., C.O. and G.A.; investigation, D.K., T.S., S.W. T.T., R.E.H., E.A., A.H., C.O. and G.A.; resources, D.K., C.O. and G.A.; writing-original draft preparation, D.K., T.S., S.W. T.T., R.E.H., E.A., A.H., C.O. and G.A.; writing-review and editing, D.K., T.S., S.W. T.T., R.E.H., E.A., A.H., C.O. and G.A.; visualization, D.K., T.S., S.W. T.T., R.E.H., E.A., A.H., C.O. and G.A.; supervision, D.K, C.O., and G.A.; funding acquisition, D.K. and G.A. 
Funding: This publication has been co-funded by the Erasmus+ Programme of the European Union (Strategic Partnership, ViMeLa, 2017-1-PL01-KA203-038675). This publication reflects the views only of the authors, the National Agency and European Commission cannot be held responsible for any use, which may be made of the information contained therein. This work has been partially supported by Estonian Research Grant (PUT638); the Estonian Centre of Excellence in IT (EXCITE), funded by the European Regional Development Fund; and the Scientific and Technological Research Council of Turkey (TÜBITAK) (116E097).

Conflicts of Interest: The authors declare no conflict of interest.

\section{References}

1. Gutmann, A.; Ben-Porath, S. Democratic education. In The Encyclopedia of Political Thought; Wiley: Hoboken, NJ, USA, 2014; pp. 863-875.

2. Wittich, C.M.; Agrawal, A.; Cook, D.A.; Halvorsen, A.J.; Mandrekar, J.N.; Chaudhry, S.; Dupras, D.M.; Oxentenko, A.S.; Beckman, T.J. E-learning in graduate medical education: Survey of residency program directors. BMC Med. Educ. 2017, 17, 114. [CrossRef] [PubMed]

3. Dewey, J. Experience and Education; Simon and Schuster: New York, NY, USA, 2007.

4. Blumenfeld, P.C.; Soloway, E.; Marx, R.W.; Krajcik, J.S.; Guzdial, M.; Palincsar, A. Motivating project-based learning: Sustaining the doing, supporting the learning. Educ. Psychol. 1991, 26, 369-398. [CrossRef]

5. Barnett, R. Improving Higher Education: Total Quality Care; ERIC; Open University Press: Bristol, PA, USA, 1992.

6. Yager, R.E. A vision for what science education should be like for the first 25 years of a new millennium. Sch. Sci. Math. 2000, 100, 327-341. [CrossRef]

7. Zheng, S.; Rosson, M.B.; Shih, P.C.; Carroll, J.M. Understanding student motivation, behaviors and perceptions in MOOCs. In Proceedings of the 18th ACM Conference on Computer Supported Cooperative Work \& Social Computing, Vancouver, Canada, 14-18 March 2015; pp. 1882-1895.

8. Richardson, J.; Swan, K. Examing social presence in online courses in relation to students' perceived learning and satisfaction. J. Asynchronous Learn. Netw. 2003, 7, 68-88.

9. Magdalene, R.; Sridharan, D. Powering E-Learning Through Technology: An Overview of Recent Trends in Educational Technologies. Online J. Distance Educ. e-Learn. 2018, 6, 60.

10. Singh, H. Building effective blended learning programs. Educ. Technol. 2003, 43, 51-54.

11. Graham, C.R. Blended learning systems. In The Handbook of Blended Learning; John Wiley \& Sons: Hoboken, NJ, USA, 2006; pp. 3-21.

12. Halverson, L.R.; Spring, K.J.; Huyett, S.; Henrie, C.R.; Graham, C.R. Blended learning research in higher education and K-12 settings. In Learning, Design, and Technology: An International Compendium of Theory, Research, Practice, and Policy; Springer, Cham, Switzerland, 2017; pp. 1-30.

13. Stockwell, B.R.; Stockwell, M.S.; Cennamo, M.; Jiang, E. Blended learning improves science education. Cell 2015, 162, 933-936. [CrossRef]

14. Balacheff, N.; Kaput, J.J. Computer-based learning environments in mathematics. In International Handbook of Mathematics Education; Springer: Dordrecht, The Netherlands, 1996; pp. 469-501.

15. Moos, D.C.; Azevedo, R. Learning with computer-based learning environments: A literature review of computer self-efficacy. Rev. Educ. Res. 2009, 79, 576-600. [CrossRef]

16. Van der Kleij, F.M.; Feskens, R.C.; Eggen, T.J. Effects of feedback in a computer-based learning environment on students' learning outcomes: A meta-analysis. Rev. Educ. Res. 2015, 85, 475-511. [CrossRef]

17. Zawacki-Richter, O.; Latchem, C. Exploring four decades of research in Computers \& Education. Comput. Educ. 2018, 122, 136-152.

18. Zhang, M.; Zhang, Z.; Chang, Y.; Aziz, E.S.; Esche, S.; Chassapis, C. Recent Developments in Game-Based Virtual Reality Educational Laboratories Using the Microsoft Kinect. Int. J. Emerg. Technol. Learn. (iJET) 2018, 13, 138-159. [CrossRef]

19. Collins, A.; Halverson, R. Rethinking Education in the Age of Technology: The Digital Revolution and Schooling in America; Teachers College Press: New York, NY, USA, 2018.

20. Atkins, D.; Brown, J.; Hammond, A. A Review of the Open Educational Resources (OER) Movement: Achievements, Challenges, and New Opportunities; Report to The William and Flora Hewlett Foundation: SAN Francisco, CA, USA, February 2007. 
21. Ally, M. Mobile Learning: Transforming the Delivery of Education and Training; Athabasca University Press: Athabasca, AB, Canada, 2009.

22. Kaye, A.T.; Rumble, G. Distance Teaching for Higher and Adult Education; Routledge: Abingdon, UK, 2018.

23. FitzGerald, E.; Kucirkova, N.; Jones, A.; Cross, S.; Ferguson, R.; Herodotou, C.; Hillaire, G.; Scanlon, E. Dimensions of personalisation in technology-enhanced learning: A framework and implications for design. Br. J. Educ. Technol. 2018, 49, 165-181. [CrossRef]

24. Lazar, I.; Panisoara, I.O. Understanding the role of modern technologies in education: A scoping review protocol. Psychreg J. Psychol. 2018, 2, 74-86.

25. Van Lieshout, M.; Egyedi, T.M.; Bijker, W.E. Social Learning Technologies: The Introduction of Multimedia in Education; Routledge: Abingdon, UK, 2018.

26. Goldin, C.; Katz, L.F. The race between education and technology. In Inequality in the 21st Century; Routledgel Abingdon, UK, 2018; pp. 49-54.

27. Hõrak, H. Computer Vision-Based Unobtrusive Physical Activity Monitoring in School by Room-Level Physical Activity Estimation: A Method Proposition. Information 2019, 10, 269. [CrossRef]

28. Bryson, S. Virtual reality: A definition history-A personal essay. arXiv 2013, arXiv:1312.4322.

29. Burdea, G.; Coiffet, P. Virtual Reality Technology; Wiley: Hoboken, NJ, USA, 2003.

30. Burdea, G.C.; Coiffet, P. Virtual Reality Technology; John Wiley \& Sons: Hoboken, NJ, USA, 2003.

31. Zhang, H. Head-mounted display-based intuitive virtual reality training system for the mining industry. Int. J. Min. Sci. Technol. 2017, 27, 717-722. [CrossRef]

32. Kamińska, D.; Sapiński, T.; Zwoliński, G.; Wiak, S.; Kucharczyk-Pośpiech, M.; Wilczyński, M. Virtual Reality as a Tool for Ophthalmic Examination. In Proceedings of the Polish Conference on Biocybernetics and Biomedical Engineering, Zielona Gora, Poland, 25-27 September 2019; pp. 94-106.

33. Nadan, T.; Alexandrov, V.; Jamieson, R.; Watson, K. Is virtual reality a memorable experience in an educational context? Int. J. Emerg. Technol. Learn. (iJET) 2011, 6, 53-57. [CrossRef]

34. Slavova, Y.; Mu, M. A comparative study of the learning outcomes and experience of VR in education. In Proceedings of the 2018 IEEE Conference on Virtual Reality and 3D User Interfaces (VR), Reutlingen, Germany, 18-22 March 2018; pp. 685-686.

35. Cochrane, T. Mobile VR in education: From the fringe to the mainstream. Int. J. Mob. Blended Learn. (IJMBL) 2016, 8, 44-60. [CrossRef]

36. Petkovska, L.; Cvetkovski, G.; Kaminska, D.; Wiak, S.; Firych-Nowacka, A.; Lefik, M.; Sapinski, T.; Zwolinski, G.; Di Barba, P.; Mognaschi, M.E.; et al. ViMeLa PROJECT: An Innovative Concept for Teaching Students in Mechatronics Using Virtual Reality. In Proceedings of the 7th Symposium On Applied Electromagnetics (SAEM'18), Podčetrtek, Slovenia, 17-20 June 2018.

37. Christou, C. Virtual reality in education. In Affective, Interactive and Cognitive Methods for E-Learning Design: Creating an Optimal Education Experience; IGI Global: Hershey, PA, USA, 2010; pp. 228-243.

38. Niemierko, B.; i Pedagogiczne, W.S. ABC Testów Osiagnięć Szkolnych; Wydawnictwa Szkolne i Pedagogiczne: Warsaw, Poland, 1975.

39. Alfalah, S.F.; Falah, J.F.; Alfalah, T.; Elfalah, M.; Muhaidat, N.; Falah, O. A comparative study between a virtual reality heart anatomy system and traditional medical teaching modalities. Virtual Real. 2019, 23, 229-234. [CrossRef]

40. Meiliang, W.; Qiaoming, P. Design of Safety Education System for Children Based on Virtual Reality Technology. In Proceedings of the 2012 International Conference on Computer Science and Electronics Engineering (ICCSEE), Hangzhou, China, 23-25 March 2012; Volume 1, pp. 196-199.

41. Tilling, S.; Tudor, A.D.; Kitchen, B.; Minocha, S. Investigating the role of virtual reality in geography via Google Expeditions. In Proceedings of the Geographical Association Annual Conference, Guildford, UK, 20-22 April 2017; pp. 1-14.

42. Zhao, J.; LaFemina, P.; Wallgrun, J.O.; Oprean, D.; Klippel, A. iVR for the geosciences. In Proceedings of the 2017 IEEE Virtual Reality Workshop on K-12 Embodied Learning through Virtual \& Augmented Reality (KELVAR), Los Angeles, CA, USA, 19 March 2017.

43. Bhagavathula, R.; Williams, B.; Owens, J.; Gibbons, R. The reality of virtual reality: A comparison of pedestrian behavior in real and virtual environments. In Proceedings of the Human Factors and Ergonomics Society Annual Meeting, 2018, Los Angeles, CA, USA, 27 September 2018; SAGE Publications: Los Angeles, CA, USA; Volume 62, pp. 2056-2060. 
44. Schwebel, D.C.; Combs, T.; Rodriguez, D.; Severson, J.; Sisiopiku, V. Community-based pedestrian safety training in virtual reality: A pragmatic trial. Accid. Anal. Prev. 2016, 86, 9-15. [CrossRef]

45. Grabowski, A.; Jankowski, J. Virtual reality-based pilot training for underground coal miners. Saf. Sci. 2015, 72, 310-314. [CrossRef]

46. Meyer, L. Students explore the earth and beyond with virtual field trips. THE J. 2016, 43, 22-25.

47. Black, E.R. Learning Then and There: An Exploration of Virtual Reality in K-12 History Education. Ph.D. Thesis, The University of Texas at Austin, Austin, TX, USA, 2017.

48. Odyssey: Arnswalde VR. Available online: http://odysseycrew.com/portfolio/ (accessed on 30 August 2018).

49. Oigara, J. Explorations of Google Cardboard 3D Virtual Reality as Geospatial Technology for Education. In Proceedings of the Society for Information Technology \& Teacher Education International Conference, Washington, DC, USA, 26 March 2018; pp. 1296-1300.

50. Ghosh, A.; Brown, V. A Comparative Study of Different 3D Interaction Techniques for Virtual Environment and Their Scopes in Education. In Proceedings of the FDLA Conference, Walford, 16 January 2018. Available online: https:/ / nsuworks.nova.edu/fdla-conference/2017/day1/20/ (accessed on 16 October 2019).

51. Craddock, I.M. Immersive Virtual Reality, Google Expeditions, and English Language Learning. Libr. Technol. Rep. 2018, 54, 7-9.

52. Pilatásig, M.; Tobar, E.; Paredes, L.; Silva, F.M.; Acurio, A.; Pruna, E.; Escobar, I.; Sánchez, Z. Virtual System for Teaching-Learning of Initial Education Using a Haptic Device. In Proceedings of the International Conference on Augmented Reality, Virtual Reality and Computer Graphics, Otranto, Italy, 24-27 June 2018; pp. 118-132.

53. Edwards, B.I.; Bielawski, K.S.; Prada, R.; Cheok, A.D. Haptic virtual reality and immersive learning for enhanced organic chemistry instruction. Virtual Real. 2019, 23, 363-373. [CrossRef]

54. Kunze, K.; Minamizawa, K.; Lukosch, S.; Inami, M.; Rekimoto, J. Superhuman sports: Applying human augmentation to physical exercise. IEEE Pervasive Comput. 2017, 16, 14-17. [CrossRef]

55. Caporusso, N.; Biasi, L.; Cinquepalmi, G.; Bevilacqua, V. An Immersive Environment for Experiential Training and Remote Control in Hazardous Industrial Tasks. In Proceedings of the International Conference on Applied Human Factors and Ergonomics, Orlando, FL, USA, 21-25 July 2018; pp. 88-97.

56. Lei, X.; Zhang, A.; Wang, B.; Rau, P.L.P. Can Virtual Reality Help Children Learn Mathematics Better? The Application of VR Headset in Children's Discipline Education. In Proceedings of the International Conference on Cross-Cultural Design, Las Vegas, NV, USA, 15-20 July 2018; pp. 60-69.

57. Sun, C.; Hu, W.; Xu, D. Navigation modes, operation methods, observation scales and background options in UI Design for high learning performance in VR-based Architectural Applications. J. Comput. Des. Eng. 2019, 6, 189-196. [CrossRef]

58. Kamińska, D.; Sapiński, T.; Aitken, N.; Della Rocca, A.; Barańska, M.; Wietsma, R. Virtual reality as a new trend in mechanical and electrical engineering education. Open Phys. 2017, 15, 936-941. [CrossRef]

59. Petkovska, L.; Cvetkovski, G.; Kaminska, D.; Wiak, S.; Firych-Nowacka, A.; Lefik, M.; Sapinski, T.; Zwolinski, G.; Di Barba, P.; Mognaschi, M.E.; et al. Virtual reality as a tool for electrical machines assembling and testing. In Proceedings of the 7th Symposium on Applied Electromagnetics SAEM'18, Podčetrtek, Slovenia, 17-20 June 2018.

60. Wang, F.; Liu, Y.; Tian, M.; Zhang, Y.; Zhang, S.; Chen, J. Application of a 3D Haptic Virtual Reality Simulation System for Dental Crown Preparation Training. In Proceedings of the 2016 8th International Conference on Information Technology in Medicine and Education (ITME), Fuzhou, China, 23-25 December 2016; pp. 424-427.

61. Kim, G.; Biocca, F. Immersion in Virtual Reality Can Increase Exercise Motivation and Physical Performance. In Proceedings of the International Conference on Virtual, Augmented and Mixed Reality, Las Vegas, NV, USA, 15-20 July 2018; pp. 94-102.

62. Pan, Z.; Cheok, A.D.; Yang, H.; Zhu, J.; Shi, J. Virtual reality and mixed reality for virtual learning environments. Comput. Graph. 2006, 30, 20-28. [CrossRef]

63. Luck, M.; Aylett, R. Applying artificial intelligence to virtual reality: Intelligent virtual environments. Appl. Artif. Intell. 2000, 14, 3-32. [CrossRef]

64. Schwienhorst, K. The 'third place'-Virtual reality applications for second language learning. ReCALL 1998, 10, 118-126. [CrossRef] 
65. Bricken, M.; Byrne, C.M. Summer students in virtual reality: A pilot study on educational applications of virtual reality technology. In Virtual Reality; Elsevier: Amsterdam, The Netherlands, 1993; pp. 199-217.

66. Bell, J.T.; Fogler, H.S. The investigation and application of virtual reality as an educational tool. In Proceedings of the American Society for Engineering Education Annual Conference, Anaheim, CA, USA, June 1995; pp. 1718-1728.

67. Lv, Z.; Li, X.; Li, W. Virtual reality geographical interactive scene semantics research for immersive geography learning. Neurocomputing 2017, 254, 71-78. [CrossRef]

68. Dakson, A.; Hong, M.; Clarke, D.B. Virtual reality surgical simulation: Implications for resection of intracranial gliomas. In Intracranial Gliomas Part I-Surgery; Karger Publishers: Basel, Switzerland, 2018; Volume 30, pp. 106-116.

69. Parkinson, A.; Kitchen, R.; Tudor, A.D.; Minocha, S.; Tilling, S. Role of smartphone-driven virtual reality field trips in inquiry-based learning. In Proceedings of the Geographical Association Annual Conference, Guildford, UK, 20-22 April 2017; pp. 1-7.

70. Saadatzi, M.N.; Pennington, R.C.; Welch, K.C.; Graham, J.H. Small-Group Technology-Assisted Instruction: Virtual Teacher and Robot Peer for Individuals with Autism Spectrum Disorder. J. Autism Dev. Disord. 2018, 48, 3816-3830. [CrossRef] [PubMed]

71. Liaw, S.Y.; Carpio, G.A.C.; Lau, Y.; Tan, S.C.; Lim, W.S.; Goh, P.S. Multiuser virtual worlds in healthcare education: A systematic review. Nurse Educ. Today 2018, 65, 136-149. [CrossRef] [PubMed]

72. Piovesan, S.D.; Passerino, L.M.; Pereira, A.S. Virtual Reality as a Tool in the Education. In Proceedings of the International Association for Development of the Information Society International Conference on Cognition and Exploratory Learning in Digital Age (CELDA), Madrid, Spain, 19-21 October 2012.

73. Pitkänen, K.; Andersen, H.V. Empowering Teachers and New Generations through Design Thinking and Digital Fabrication Learning Activities. In Proceedings of the Conference on Creativity and Making in Education, New York, NY, USA, 18 June 2018; pp. 55-63.

74. Ip, H.H.; Wong, S.W.; Chan, D.F.; Byrne, J.; Li, C.; Yuan, V.S.; Lau, K.S.; Wong, J.Y. Enhance emotional and social adaptation skills for children with autism spectrum disorder: A virtual reality enabled approach. Comput. Educ. 2018, 117, 1-15. [CrossRef]

75. Kavanagh, S.; Luxton-Reilly, A.; Wuensche, B.; Plimmer, B. A systematic review of Virtual Reality in education. Themes Sci. Technol. Educ. 2017, 10, 85-119.

76. Pantelidis, V.S. Virtual reality and engineering education. Comput. Appl. Eng. Educ. 1997, 5, 3-12. [CrossRef]

77. Gandhi, R.D.; Patel, D.S. Virtual Reality-Opportunities and Challenges. Virtual Real. 2018, 5; pp. $482-490$.

78. Valdez, M.T.; Ferreira, C.M.; Martins, M.J.M.; Barbosa, F.M. 3D virtual reality experiments to promote electrical engineering education. In Proceedings of the 2015 International Conference on Information Technology Based Higher Education and Training (ITHET), Lisbon, Portugal, 11-13 June 2015; pp. 1-4.

79. Hurtado, C.V.; Valerio, A.R.; Sanchez, L.R. Virtual reality robotics system for education and training. In Proceedings of the Electronics, Robotics and Automotive Mechanics Conference (CERMA), Morelos, Mexico, 28 September 2010; pp. 162-167.

80. Román-Ibáñez, V.; Pujol-López, F.A.; Mora-Mora, H.; Pertegal-Felices, M.L.; Jimeno-Morenilla, A. A Low-Cost Immersive Virtual Reality System for Teaching Robotic Manipulators Programming. Sustainability 2018, 10, 1102. [CrossRef]

81. Put, J.; Michiels, N.; Di Fiore, F.; Van Reeth, F. Capturing Industrial Machinery into Virtual Reality. In Proceedings of the International Conference on Articulated Motion and Deformable Objects, Palma de Mallorca, Spain, 12-13 July 2018; pp. 44-52.

82. Dinis, F.M.; Guimarães, A.S.; Carvalho, B.R.; Martins, J.P.P. Virtual and augmented reality game-based applications to civil engineering education. In Proceedings of the 2017 IEEE Global Engineering Education Conference (EDUCON), Athens, Greece, 25-28 April 2017; pp. 1683-1688.

83. Dinis, F.M.; Guimarães, A.S.; Carvalho, B.R.; Martins, J.P.P. Development of virtual reality game-based interfaces for civil engineering education. In Proceedings of the 2017 IEEE Global Engineering Education Conference (EDUCON), Athens, Greece, 25-28 April 2017; pp. 1195-1202.

84. Sampaio, A.Z.; Martins, O. VR model of bridge construction: a didactic application. In Proceedings of the Virtual Reality International Conference-Laval Virtual 2017, New York, NY, USA, 22-24 March 2017; p. 21. 
85. dos Santos, M.C.C.; Sangalli, V.A.; Pinho, M.S. Evaluating the Use of Virtual Reality on Professional Robotics Education. In Proceedings of the 2017 IEEE 41st Annual Computer Software and Applications Conference (COMPSAC), Turin, Italy, 4-8 July 2017; Volume 1, pp. 448-455.

86. Żywicki, K.; Zawadzki, P.; Górski, F. Virtual reality production training system in the scope of intelligent factory. In Proceedings of the International Conference on Intelligent Systems in Production Engineering and Maintenance, Wroclaw, Poland, 28-29 September 2017; pp. 450-458.

87. Riva, G. Applications of virtual environments in medicine. Methods Inf. Med. 2003, 42, 524-534. [CrossRef]

88. Górski, F.; Buń, P.; Wichniarek, R.; Zawadzki, P.; Hamrol, A. Effective Design of Educational Virtual Reality Applications for Medicine using Knowledge-Engineering Techniques. Eurasia J. Math. Sci. Technol. Educ. 2017, 13, 395-416. [CrossRef]

89. Radia, M.; Arunakirinathan, M.; Sibley, D. A guide to eyes: ophthalmic simulators. Bull. R. Coll. Surg. Engl. 2018, 100, 169-171. [CrossRef]

90. Seo, J.H.; Smith, B.M.; Cook, M.; Malone, E.; Pine, M.; Leal, S.; Bai, Z.; Suh, J. Anatomy builder VR: applying a constructive learning method in the virtual reality canine skeletal system. In Proceedings of the International Conference on Applied Human Factors and Ergonomics, Los Angeles, California, USA, 17-21 July 2017; pp. 245-252.

91. Vankipuram, A.; Khanal, P.; Ashby, A.; Vankipuram, M.; Gupta, A.; DrummGurnee, D.; Josey, K.; Smith, M. Design and development of a virtual reality simulator for advanced cardiac life support training. IEEE J. Biomed. Health Inform. 2014, 18, 1478-1484. [CrossRef] [PubMed]

92. Elliman, J.; Loizou, M.; Loizides, F. Virtual reality simulation training for student nurse education. In Proceedings of the 2016 8th International Conference on Games and Virtual Worlds for Serious Applications (VS-Games), Barcelona, Spain, 7-9 September 2016; pp. 1-2.

93. Harrison, B.; Oehmen, R.; Robertson, A.; Robertson, B.; De Cruz, P.; Khan, R.; Fick, D. Through the Eye of the Master: The Use of Virtual Reality in the Teaching of Surgical Hand Preparation. In Proceedings of the 2017 IEEE 5th International Conference on Serious Games and Applications for Health (SeGAH), Perth, WA, Australia, 2-4 April 2017; pp. 1-6.

94. Song, D.; Norman, M.L. Cosmic Explorer: A virtual reality environment for exploring cosmic data. In Proceedings of 1993 IEEE Research Properties in Virtual Reality Symposium, San Jose, CA, USA, 25-26 October 1993; pp. 75-79.

95. Billinghurst, M. Augmented reality in education. New Horizons Learn. 2002, 12, 1-5.

96. Yair, Y.; Schur, Y.; Mintz, R. A “Thinking Journey" to the planets using scientific visualization technologies: Implications to astronomy education. J. Sci. Educ. Technol. 2003, 12, 43-49. [CrossRef]

97. Mintz, R.; Litvak, S.; Yair, Y. 3D-virtual reality in science education: An implication for astronomy teaching. J. Comput. Math. Sci. Teach. 2001, 20, 293-305.

98. Klimenko, S. Virtual planetarium: Learning astronomy in virtual reality. In Proceedings of the EdMedia+ Innovate Learning Association for the Advancement of Computing in Education (AACE), Waynesville, NC, USA, 21-26 June 2004; pp. 2154-2157.

99. Winn, W.; Bricken, W. Designing virtual worlds for use in mathematics education: The example of experiential algebra. Educ. Technol. 1992, 32, 12-19.

100. Kaufmann, H.; Schmalstieg, D. Mathematics and geometry education with collaborative augmented reality. In Proceedings of the ACM SIGGRAPH 2002 Conference Abstracts and Applications, San Antonio, TX, USA, 21-26 July 2002; pp. 37-41.

101. Hwang, W.Y.; Hu, S.S. Analysis of peer learning behaviors using multiple representations in virtual reality and their impacts on geometry problem solving. Comput. Educ. 2013, 62, 308-319. [CrossRef]

102. Kaufmann, H.; Schmalstieg, D.; Wagner, M. Construct3D: a virtual reality application for mathematics and geometry education. Educ. Inf. Technol. 2000, 5, 263-276. [CrossRef]

103. Pasqualotti, A.; Freitas, C.M.D.S. MAT3D: A virtual reality modeling language environment for the teaching and learning of mathematics. Cyber Psychol. Behav. 2002, 5, 409-422. [CrossRef]

104. Mathur, A.S. Low cost virtual reality for medical training. In Proceedings of the 2015 IEEE Virtual Reality (VR), Arles, France, 23-27 March 2015; pp. 345-346.

105. Thomas, J.; Bashyal, R.; Goldstein, S.; Suma, E. MuVR: A multi-user virtual reality platform. In Proceedings of the 2014 IEEE Virtual Reality (VR), Minneapolis, MN, USA, 29 March 2014; pp. 115-116. 
106. Messner, J.I.; Yerrapathruni, S.C.; Baratta, A.J.; Whisker, V.E. Using virtual reality to improve construction engineering education. In Proceedings of the American Society for Engineering Education Annual Conference \& Exposition, Nashville, TN, USA, 22-25 June 2003.

107. Martín-Gutiérrez, J.; Mora, C.E.; Añorbe-Díaz, B.; González-Marrero, A. Virtual technologies trends in education. EURASIA J. Math. Sci. Technol. Educ. 2017, 13, 469-486. [CrossRef]

108. Brown, A.; Green, T. Virtual reality: Low-cost tools and resources for the classroom. TechTrends 2016, 60, 517-519. [CrossRef]

109. Blyth, C. Immersive technologies and language learning. Foreign Lang. Ann. 2018, 51, 225-232. [CrossRef]

110. Parmar, D.; Isaac, J.; Babu, S.V.; D’Souza, N.; Leonard, A.E.; Jörg, S.; Gundersen, K.; Daily, S.B. Programming moves: Design and evaluation of applying embodied interaction in virtual environments to enhance computational thinking in middle school students. In Proceedings of the 2016 IEEE Virtual Reality (VR), Greenville, SC, USA, 19-23 March 2016; pp. 131-140.

111. Serafin, S.; Adjorlu, A.; Nilsson, N.; Thomsen, L.; Nordahl, R. Considerations on the use of virtual and augmented reality technologies in music education. In Proceedings of the 2017 IEEE Virtual Reality Workshop on K-12 Embodied Learning through Virtual \& Augmented Reality (KELVAR), Los Angeles, CA, USA, 19 March 2017; pp. 1-4.

112. Zhang, K.; Liu, S.J. The application of virtual reality technology in physical education teaching and training. In Proceedings of the 2016 IEEE International Conference on Service Operations and Logistics, and Informatics (SOLI), Beijing, China, 10-12 July 2016; pp. 245-248.

113. Melatti, M.; Johnsen, K. Virtual Reality mediated instruction and learning. In Proceedings of the 2017 IEEE Virtual Reality Workshop on K-12 Embodied Learning through Virtual \& Augmented Reality (KELVAR), Los Angeles, CA, USA, 19 March 2017; pp. 1-6.

114. Li, X.; Yi, W.; Chi, H.L.; Wang, X.; Chan, A.P. A critical review of virtual and augmented reality (VR/AR) applications in construction safety. Autom. Constr. 2018, 86, 150-162. [CrossRef]

115. Velosa, J.D.; Cobo, L.; Castillo, F.; Castillo, C. Methodological Proposal for Use of Virtual Reality VR and Augmented Reality AR in the Formation of Professional Skills in Industrial Maintenance and Industrial Safety. In Online Engineering E Internet of Things; Springer: Berlin/Heidelberg, Germany, 2018; pp. 987-1000.

116. Pena, A.M.; Ragan, E.D. Contextualizing construction accident reports in virtual environments for safety education. In Proceedings of the 2017 IEEE Virtual Reality (VR), Los Angeles, CA, USA, 18-22 March 2017; pp. 389-390.

117. Chittaro, L.; Corbett, C.L.; McLean, G.; Zangrando, N. Safety knowledge transfer through mobile virtual reality: A study of aviation life preserver donning. Saf. Sci. 2018, 102, 159-168. [CrossRef]

118. Smyth, D.L.; Fennell, J.; Abinesh, S.; Karimi, N.B.; Glavin, F.G.; Ullah, I.; Drury, B.; Madden, M.G. A Virtual Environment with Multi-Robot Navigation, Analytics, and Decision Support for Critical Incident Investigation. arXiv 2018, arXiv:1806.04497.

119. Sankaranarayanan, G.; Wooley, L.; Hogg, D.; Dorozhkin, D.; Olasky, J.; Chauhan, S.; Fleshman, J.W.; De, S.; Scott, D.; Jones, D.B. Immersive virtual reality-based training improves response in a simulated operating room fire scenario. Surg. Endosc. 2018, 32, 3439-3449. [CrossRef]

120. Agrawal, R.; Knodler, M.; Fisher, D.L.; Samuel, S. Virtual Reality Headset Training: Can It Be Used to Improve Young Drivers' Latent Hazard Anticipation and Mitigation Skills. Transp. Res. Rec. 2018, 2672, 20-30. [CrossRef]

121. Schultheis, M.T.; Rizzo, A.A. The application of virtual reality technology in rehabilitation. Rehabil. Psychol. 2001, 46, 296. [CrossRef]

122. Burke, S.L.; Bresnahan, T.; Li, T.; Epnere, K.; Rizzo, A.; Partin, M.; Ahlness, R.M.; Trimmer, M. Using Virtual Interactive Training Agents (ViTA) with Adults with Autism and Other Developmental Disabilities. J. Autism Dev. Disord. 2018, 48, 905-912. [CrossRef]

123. Cuperus, A.A.; Keizer, A.; Evers, A.W.; van den Houten, M.M.; Teijink, J.A.; van der Ham, I.J. Manipulating spatial distance in virtual reality: Effects on treadmill walking performance in patients with intermittent claudication. Comput. Hum. Behav. 2018, 79, 211-216. [CrossRef]

124. Arter, P.; Brown, T.; Law, M.; Barna, J.; Fruehan, A.; Fidiam, R. Virtual Reality: Improving Interviewing Skills in Individuals with Autism Spectrum Disorder. In Proceedings of the Society for Information Technology \& Teacher Education International Conference, Association for the Advancement of Computing in Education (AACE), Washington, DC, USA, 26 March 2018; pp. 1086-1088. 
125. Alimanova, M.; Borambayeva, S.; Kozhamzharova, D.; Kurmangaiyeva, N.; Ospanova, D.; Tyulepberdinova, G.; Gaziz, G.; Kassenkhan, A. Gamification of Hand Rehabilitation Process Using Virtual Reality Tools: Using Leap Motion for Hand Rehabilitation. In Proceedings of the IEEE International Conference on Robotic Computing (IRC), Taichung, Taiwan, 10-12 April 2017; pp. 336-339.

126. Sobota, B.; Korečko, Š.; Pastornickỳ, P.; Jacho, L. Virtual-reality technologies in the process of handicapped school children education. In Proceedings of the 2016 International Conference on Emerging eLearning Technologies and Applications (ICETA), Vysoke Tatry, Slovakia, 24-25 November 2016; pp. 321-326.

127. Ravi, D.; Kumar, N.; Singhi, P. Effectiveness of virtual reality rehabilitation for children and adolescents with cerebral palsy: an updated evidence-based systematic review. Physiotherapy 2017, 103, 245-258. [CrossRef] [PubMed]

128. da Fonseca, E.P.; da Silva, N.M.R.; Pinto, E.B. Therapeutic effect of virtual reality on post-stroke patients: randomized clinical trial. J. Stroke Cerebrovasc. Dis. 2017, 26, 94-100. [CrossRef] [PubMed]

129. Brooke, J. SUS: A quick and dirty usability scale. Usability Eval. Ind. 1996, 189, 4-7.

130. Hussein, M.; Nätterdal, C. The Benefits of Virtual Reality in Education-A Comparision Study. Ph.D. Thesis, Chalmers University of Technology, Gothenburg, Sweden, 2015.

131. Bowen, M.M. Effect of Virtual Reality on Motivation and Achievement of Middle-School Students. Ph.D. Thesis, The University of Memphis, Memphis, TN, USA, 2018.

132. Ludlow, B.L. Virtual reality: Emerging applications and future directions. Rural. Spec. Educ. Q. 2015, 34, 3-10. [CrossRef]

133. Gayol, Y.; Schied, F. Cultural imperialism in the virtual classroom: Critical pedagogy in transnational distance education. In Proceedings of the 18th Conference of the International Council for Distance Education, State College, PA, USA, 2-6 June 1997; pp. 1-17.

134. Mayes, J.T.; Fowler, C.J. Learning technology and usability: A framework for understanding courseware. Interact. Comput. 1999, 11, 485-497. [CrossRef]

135. Thorsteinsson, G.; Shavinina, L. Developing an understanding of the pedagogy of using a virtual reality learning environment (VRLE) to support innovation education. In The Routledge International Handbook of Innovation Education; Shavinina, L.V., Ed.; Routledge: Oxford, UK, 2013; pp. 456-470.

136. Fowler, C. Virtual reality and learning: Where is the pedagogy? Br. J. Educ. Technol. 2015, 46, 412-422. [CrossRef]

137. Zyda, M. From visual simulation to virtual reality to games. Computer 2005, 38, 25-32. [CrossRef]

138. Blazauskas, T.; Maskeliunas, R.; Bartkute, R.; Kersiene, V.; Jurkeviciute, I.; Dubosas, M. Virtual Reality in Education: New Ways to Learn. In Proceedings of the International Conference on Information and Software Technologies, Druskininkai, Lithuania, 12-14 October 2017; pp. 457-465.

139. Coburn, J.Q.; Freeman, I.; Salmon, J.L. A review of the capabilities of current low-cost virtual reality technology and its potential to enhance the design process. J. Comput. Inf. Sci. Eng. 2017, 17, 031013. [CrossRef]

140. Costello, P.J. Health And Safety Issues Associated with Virtual Reality: A Review of Current Literature; Advisory Group on Computer Graphics: Loughborough, UK, 1997.

141. Davis, S.; Nesbitt, K.; Nalivaiko, E. Comparing the onset of cybersickness using the Oculus Rift and two virtual roller coasters. In Proceedings of the 11th Australasian Conference on Interactive Entertainment (IE 2015), Sydney, Australia, 27-30 January 2015; Volume 27, p. 30.

142. Regan, C. An investigation into nausea and other side-effects of head-coupled immersive virtual reality. Virtual Real. 1995, 1, 17-31. [CrossRef]

(C) 2019 by the authors. Licensee MDPI, Basel, Switzerland. This article is an open access article distributed under the terms and conditions of the Creative Commons Attribution (CC BY) license (http:/ / creativecommons.org/licenses/by/4.0/). 